\title{
A comprehensive inventory of ship traffic exhaust emissions in the European sea areas in 2011
}

\author{
J.-P. Jalkanen, L. Johansson, and J. Kukkonen \\ Finnish Meterological Institute, P.O. Box 503, 00101 Helsinki, Finland \\ Correspondence to: J.-P. Jalkanen (jukka-pekka.jalkanen@fmi.fi)
}

Received: 19 December 2014 - Published in Atmos. Chem. Phys. Discuss.: 11 March 2015

Revised: 30 November 2015 - Accepted: 14 December 2015 - Published: 14 January 2016

\begin{abstract}
Emissions originating from ship traffic in European sea areas were modelled using the Ship Traffic Emission Assessment Model (STEAM), which uses Automatic Identification System data to describe ship traffic activity. We have estimated the emissions from ship traffic in the whole of Europe in 2011. We report the emission totals, the seasonal variation, the geographical distribution of emissions, and their disaggregation between various ship types and flag states. The total ship emissions of $\mathrm{CO}_{2}, \mathrm{NO}_{x}, \mathrm{SO}_{x}, \mathrm{CO}$, and $\mathrm{PM}_{2.5}$ in Europe for year 2011 were estimated to be 121, 3.0, $1.2,0.2$, and 0.2 million tons, respectively. The emissions of $\mathrm{CO}_{2}$ from the Baltic Sea were evaluated to be more than a half $(55 \%)$ of the emissions of the North Sea shipping; the combined contribution of these two sea regions was almost as high $(88 \%)$ as the total emissions from ships in the Mediterranean. As expected, the shipping emissions of $\mathrm{SO}_{x}$ were significantly lower in the $\mathrm{SO}_{x}$ Emission Control Areas, compared with the corresponding values in the Mediterranean. Shipping in the Mediterranean Sea is responsible for 40 and $49 \%$ of the European ship emitted $\mathrm{CO}_{2}$ and $\mathrm{SO}_{x}$ emissions, respectively. In particular, this study reported significantly smaller emissions of $\mathrm{NO}_{x}, \mathrm{SO}_{x}$, and $\mathrm{CO}$ for shipping in the Mediterranean than the EMEP inventory; however, the reported $\mathrm{PM}_{2.5}$ emissions were in a fairly good agreement with the corresponding values reported by EMEP. The vessels registered to all EU member states are responsible for $55 \%$ of the total $\mathrm{CO}_{2}$ emitted by ships in the study area. The vessels under the flags of convenience were responsible for $25 \%$ of the total $\mathrm{CO}_{2}$ emissions.
\end{abstract}

\section{Introduction}

The cornerstone of air quality modelling research is an up-to-date description of emissions from all sectors of anthropogenic (i.e. industry, agriculture, transport) and nonanthropogenic (i.e biogenic, desert dust, wildland fires) activities. However, information on emissions may have limited dynamical features, such as the geographical or temporal variations of emissions. This is especially important for transport emissions, which vary substantially both spatially and temporally.

Determination of shipping activity has previously been one of the largest unknowns in assessing the emissions from the maritime transport sector. The traffic activities of shipping in Europe are nowadays well known, as compared with vehicular traffic; this was not the case previously. The introduction of automatic vessel position reporting systems, such as the Automatic Identification System (AIS), have significantly reduced the uncertainty concerning ship activities and their geographical distribution. Nowadays, all vessels larger than the $300 \mathrm{t}$ size limit globally report their position with a few second intervals; this has resulted in an availability of information on ship activities at an unprecedented level of detail. The ship emission inventories, which are based on such automated identification systems, have several significant advantages over the previously developed approaches. Such inventories are based on time-dependent, high-resolution dynamic traffic patterns, which can also allow for the effects of changing conditions, such as, e.g. marine and meteorological conditions (e.g. harsh winter conditions and sea ice cover) or weather routing.

Previous studies concerning the ship emissions in Europe have been based on statistics of cargo volumes (Schrooten et al., 2009), vessel arrival and/or departure times (Whall et 
al., 2002), voluntary weather reports from ships (ICOADS, Corbett et al., 2007) or search and rescue services (AMVER, Endresen et al., 2003; Wang et al., 2008). None of these data sources is able to reflect the total ship activity with full flexibility of traffic activity and temporal changes. Inconsistencies can exist between geographical emission inventories and satellite observations of pollutants (Vinken et al., 2014). Furthermore, important emission sources, like ships in harbours have been often neglected from regional emission studies.

The availability of the shipping activity data for research can be a challenging task; however, there are several options for data acquisition. Data collected by maritime authorities are rarely available for research purposes. However, there are networks of volunteers maintaining AIS base stations; activity data can therefore either be shared or are commercially available. Most satellite AIS data sets are available from commercial service providers, but also national space programs may provide access to these. Automatic AIS data collection facilitates annually updated ship emissions in the EU waters; however, the coverage area should be expanded to the Northeast Atlantic Ocean. This could be done with the inclusion of other activity data sources, such as, e.g. the satellite AIS data, which could be used to extend the AIS coverage, e.g. to fully cover the EMEP modelling domain.

In this work, we present emissions for European sea regions, which are covered by the terrestrial network of AIS base stations. In general, European seas are relatively densely trafficked, especially in regions in which intercontinental ship traffic intersects with busy short sea shipping routes. The vessel activity data from this area have been collected at the operational Vessel Traffic Services centre at the European Maritime Safety Agency. This centralized data archive allows one of the most comprehensive high-resolution sources of vessel activity on a continental scale. The modelling approach of the present study can be largely automated, which facilitates annual updates of large-scale ship emissions. This allows, e.g for the inclusion of the impacts of policy changes, such as sulphur reductions, to be included in the emission inventories used in air quality applications.

We have used the Ship Traffic Emission Assessment Model (Jalkanen et al., 2009, 2012; Johansson et al., 2013) which combines the vessel activity (AIS data) with vesselspecific information of main and auxiliary engines. This allows the determination of vessel-specific emissions, which are based on the detailed technical information of fuelconsuming systems onboard. Fuel type used during harbour stays or open seas will be determined from actual vessel activity and engine characteristics taking possible sulphur restrictions in specific regions into account. The fuel type assignment (residuals/distillates) is determined from technical specifications of ships' engines which can provide a more realistic description of the use of various marine fuels than fleet-wide adoption of residual fuels.

The aim of this study is to present a comprehensive inventory of ship traffic exhaust emissions for a number of con- taminants $\left(\mathrm{CO}_{2}, \mathrm{NO}_{x}, \mathrm{SO}_{x}, \mathrm{PM}_{2.5}, \mathrm{CO}\right)$ in European sea areas, utilizing the STEAM ship emission model (Jalkanen et al., 2009, 2012; Johansson, 2013). A more specific aim is to geographically present and discuss the high-resolution spatial distributions of shipping emissions for selected species, and the shares of emissions in terms of the various ship types and flag states. We have also identified the 30 highest emission intensities in the European sea and harbour areas; these regions contain the highest amounts of predicted shipping emissions of $\mathrm{CO}_{2}$ within a radius of $10 \mathrm{~km}$. We aim also to compare the numerical values of this new emission inventory with the corresponding values presented in some previous inventories on the emissions originated from European shipping.

\section{Materials and methods}

\subsection{Geographical domain and input data sets}

This modelling approach uses as input values the position reports generated by the automatic identification system (AIS); this system is globally on-board in every vessel that weighs more than $300 \mathrm{t}$. The AIS system provides automatic updates of the vessel positions and instantaneous speeds of ships at intervals of a few seconds. For this paper, we used the AIS messages received by the terrestrial AIS network and provided by the European Maritime Safety Agency (EMSA). We extracted the data that corresponded to the year 2011; the data contained more than $10^{9}$ archived AIS messages. The data have been collected from the terrestrial AIS base station network of the EU member states. The coverage of this network is illustrated in Fig. 1.

Most of the European sea areas are well represented in these data. However, the Arctic Ocean has not been included. Extensive open-sea areas, such as the Atlantic Ocean, are also not completely represented, due to the limited reception range of the terrestrial AIS base station network. There are also spatial gaps of the data in the southernmost parts of the Mediterranean, especially near the northern African coastline. The data did not include position reports from any of the African countries; however, the ship activity in this area is significantly lower than in the northern parts of the Mediterranean. This was shown with an independent investigation of satellite AIS data sets obtained from the Norwegian Coastal Administration (detailed results not shown here). The data from inland waterways in Europe have been included, but cannot be taken to fully reflect the inland shipping, as the IMO SOLAS regulation does not require the use of AIS from these vessels.

The model requires as input also the detailed technical specifications of all fuel-consuming systems on-board and other relevant technical details for all the ships considered. Such technical specifications were therefore collected and archived from various sources of information; the data from 


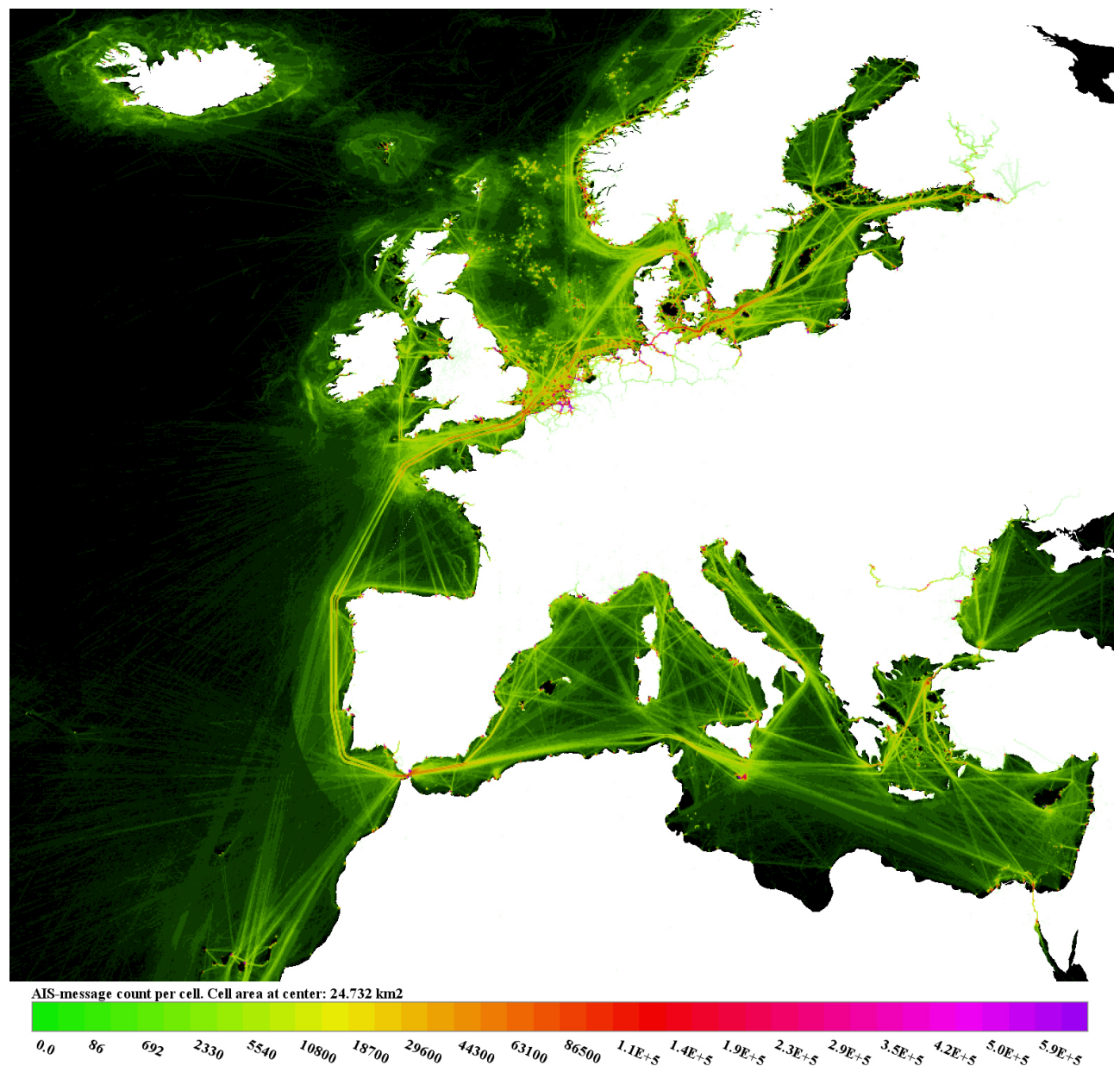

Figure 1. The geographical coverage of the terrestrial AIS network in Europe. The colour scale illustrates the number of position reports per unit area, received in the EU sea areas in 2011.

IHS Fairplay (IHS, 2014) was the most significant source. The technical data were supplemented with material from several other companies and agencies. These included the following: Det Norske Veritas, Nippon Kaiji Kyokai, Bureau Veritas, Germanischer Lloyd American Bureau of Shipping, publicly available ship registers (such as the Korean, Norwegian, and Russian ship registers), ship owners and engine manufacturers. Fuel type was determined based on the properties of engines, such as power output, angular velocity and stroke type. The sulphur content was assigned based on the current regulations in European sea areas, such as the MARPOL Annex VI (IMO, 2008) and the EU Sulphur Directive.

The technical specifications were collected and archived for more than 65000 vessels that have an International Maritime Organization (IMO) number. This set of ships represents a majority of the global commercial fleet. In addition to these vessels, the AIS position reports were received from more than 35500 vessels, for which the technical data could not be determined based on the information from classification societies, such as the Lloyds Register. In addition to the
IMO number, the vessel Maritime Mobile Service Identity (MMSI) code was used as a secondary key in searching vessel data from ship databases.

However, the vessel data were not received for a vast majority of vessels that transmitted the MMSI code (and no IMO number) in AIS data. An additional attempt to identify these vessels with internet search engines using MMSI code was made for 5000 vessels, which had the largest fuel consumption. This revealed some potentially large vessels, but the impact of this step on overall $\mathrm{CO}_{2}$ emissions was just over one percent. Clearly, the default method of assuming those vessels small, which do not transmit IMO registry number, introduces uncertainty to overall results, but the impact is negligible.

\subsection{The STEAM model and its application}

The emissions presented in this paper were evaluated using the Ship Traffic Emission Assessment Model (STEAM). A brief overview of this model is presented in the following; for a more detailed description, the reader is referred to Jalkanen 
et al. (2009, 2012) and Johansson et al. (2013). This study does not introduce any refinement of the model.

The STEAM model was used to combine the AIS-based information with the detailed technical knowledge of the ships. This combined information is used to predict vessel water resistance and instantaneous engine power of main and auxiliary engines. The model predicts as output both the instantaneous fuel consumption and the emissions of selected pollutants. The fuel consumption and emissions are computed separately for each vessel, by using archived regional scale AIS data results in a regional emission inventory. The STEAM emission model allows for the influences of the high-resolution travel routes and ship speeds, engine load, fuel sulfur content, multi-engine set-ups, abatement methods and the effects of waves (Jalkanen et al., 2012; Johansson et al., 2013).

The STEAM model includes a possibility to model some environmental effects on ships, such as the effects of waves and the influence of sea currents. However, for simplicity these factors were not taken into account in this study. The waves increase fuel consumption and emissions, whereas the direct effects of the wind and sea currents can be negative or positive. In considering long timescales and extensive regions, the net influences of direct wind effects and sea currents are expected to be fairly small. It would be possible also to use satellite-based AIS messages as input values of the model; however, for simplicity these were not used in this study, except for the above-mentioned confirmation of lack of significant vessel activity in the southern Mediterranean Sea.

The emissions of $\mathrm{NO}_{x}$ were modelled as a function of crankshaft angular velocity (revolutions per minute, rpm), according to the IMO Tier I and II rules (IMO, 2008). Tier I rule was applied also to those ships that were built before 2000; this assumption can result in a slight underestimation of emissions originated from these vessels. The effects of emission abatement techniques were also modelled, and certified emission factors have been used whenever possible. The emission certificates were provided by a group of ship owners, the emissions of these vessels had been measured by an accredited laboratory, in order to obtain a discount in the system of Swedish fairway dues. However, the vessels that were equipped with emission abatement techniques or had been subject to certified emissions represented less than $1 \%$ of the ships included in this study.

We have included in the modelling most of the various engine setups, such as gas turbines, diesel electric and mechanical power transmission, nuclear vessels and sailboats. We allowed for the fact that the operation of a shaft generator is possible for vessels, which have been indicated to have geared drives or power take-off systems. The modelled values of engine loads also take into account multi-engine setups and load balancing of operational engines.

The STEAM model simulates the required power of the main and auxiliary engines by determining the required power level set up that corresponds to the speed value in the AIS messages. All ships are modelled individually, and the modelling takes into account the differences in hull form, propeller efficiency, shaft generators and auxiliary engine usage. The sulphur content of the fuel has been modelled explicitly for each vessel and its engines. We have allowed for the sulphur reduction techniques and the influences of the regulations regarding fuel sulphur content in various regions and during various time periods (Johansson et al., 2013).

In cases, in which more detailed information could not be obtained from engine manufacturers, the Specific Fuel Oil Consumption (SFOC) has been modelled based on the methods in the second IMO GHG report (Buhaug et al., 2009). The SFOC is modelled as a function of engine load. In the model, low engine load levels can increase SFOC up to $25 \%$. Operating engines outside their optimal working range (without de-rating) will lead to increased SFOC and emission factors. The emissions of particulate matter, sulphate and water are modelled as a function of the fuel sulphur content. All vessels have been treated as single displacement hulls; catamarans and hydrofoil vessels were not separately modelled. The currently modelled pollutants are $\mathrm{NO}_{x}, \mathrm{SO}_{x}, \mathrm{CO}, \mathrm{CO}_{2}$, $\mathrm{EC}, \mathrm{OC}$, ash, and hydrated $\mathrm{SO}_{4}$. The model can also be used to generate vessel-specific emission inventories, and to predict the amount of consumed fuel. The transport work (cargo payload) is described as the product of the weight of cargo transported and the distance travelled (commonly in units of ton $\mathrm{km}$ ). In this work we adopted the scheme reported by the second IMO GHG study (Buhaug et al., 2009).

\section{Detection of locations with the highest shipping emissions of $\mathrm{CO}_{2}$}

We have evaluated in more detail the emissions from locations with an especially high emission intensity, which we refer to as shipping emission "hotspots". The STEAM model has been executed on a resolution of approximately $2.5 \mathrm{~km} \times 2.5 \mathrm{~km}$ in the EU region. For the evaluation of hotspots the resulting $\mathrm{CO}_{2}$ emission grid has subsequently been evaluated using the following rules:

1. The sum of emissions in the vicinity of each grid cell has been calculated within a radius of $10 \mathrm{~km}$ (such a domain contains approximately 44 closest grid cells).

2. The sum (if high enough) along with centre coordinates are placed in the list of top 30 highest ranking $\mathrm{CO}_{2}$ hotspots.

3. The first and second steps are repeated until each cell in the emission grid has been once the candidate emission hotspot.

This analysis also indicates the areas with the highest ship fuel consumption, whether this occurs in harbour areas or along shipping lanes. 
Table 1. Emissions and shipping statistics in the SafeSeaNet area in 2011. The section "All ships" includes also emissions from unidentified vessels. "IMO registered" refers to commercial ships with specified IMO number. In the section "GT", eight vessel size categories and their contributions to emitted $\mathrm{CO}_{2}$ are presented. The $\mathrm{NO}_{x}$ emissions have been calculated as $\mathrm{NO}_{2}$ and $\mathrm{SO}_{x}$ as $\mathrm{SO}_{2}$.

\begin{tabular}{|c|c|c|c|c|c|c|c|c|c|}
\hline$E U-2011$ & & $\begin{array}{r}\mathrm{CO}_{2} \\
(\mathrm{t})\end{array}$ & $\begin{array}{r}\mathrm{NO}_{x} \\
(\mathrm{t})\end{array}$ & $\begin{array}{r}\mathrm{SO}_{x} \\
(\mathrm{t})\end{array}$ & $\begin{array}{r}\mathrm{PM}_{2.5} \\
(\mathrm{t})\end{array}$ & $\begin{array}{r}\mathrm{CO} \\
(\mathrm{t})\end{array}$ & $\begin{array}{r}\text { Payload } \\
\left(10^{9} \mathrm{t} \times \mathrm{km}\right)\end{array}$ & Ships & $\begin{array}{r}\text { Travel } \\
\left(10^{6} \mathrm{~km}\right)\end{array}$ \\
\hline \multirow[t]{3}{*}{ All } & & 120722000 & 2964300 & 1208000 & 181600 & 197000 & 10540 & 47233 & 889 \\
\hline & IMO & 118709900 & 2930900 & 1201500 & 179900 & 194100 & 10540 & 27728 & 827 \\
\hline & Unidentified & 2012100 & 33300 & 6500 & 1600 & 2800 & 0 & 19505 & 61 \\
\hline \multirow[t]{11}{*}{ Region } & Mediterranean Sea & 48344100 & 1228600 & 594800 & 82900 & 77400 & 4400 & - & 288 \\
\hline & Atlantic Ocean & 19276900 & 511200 & 272600 & 36600 & 32900 & 2349 & - & 124 \\
\hline & North Sea & 20736000 & 477400 & 108200 & 22100 & 35800 & 1463 & - & 190 \\
\hline & Baltic Sea & 15004000 & 328800 & 83900 & 16200 & 21500 & 864 & - & 128 \\
\hline & English Channel & 6699900 & 171700 & 40200 & 7700 & 10800 & 677 & - & 47 \\
\hline & Irish \& British Seas & 4975500 & 121900 & 59000 & 8200 & 8000 & 421 & - & 41 \\
\hline & Norwegian Sea & 2399200 & 49500 & 17900 & 2900 & 4000 & 104 & - & 35 \\
\hline & Black Sea & 1305700 & 32600 & 14100 & 2000 & 2400 & 145 & - & 15 \\
\hline & Bay of Biscay & 865800 & 19300 & 8600 & 1200 & 1400 & 56 & - & 9 \\
\hline & Inland & 790400 & 15600 & 5300 & 900 & 1600 & 40 & - & 10 \\
\hline & Red Sea & 224400 & 5200 & 2300 & 300 & 400 & 21 & - & 1 \\
\hline \multirow[t]{10}{*}{ Ship types } & Container ship & 34089400 & 924300 & 414000 & 59200 & 67600 & 3440 & 1213 & 131 \\
\hline & Tanker & 26145600 & 668000 & 273500 & 41000 & 38400 & 3616 & 2879 & 160 \\
\hline & Cargo ship & 20078800 & 508600 & 208800 & 30400 & 34500 & 2887 & 5220 & 285 \\
\hline & RoPaX & 16956700 & 359900 & 127700 & 21000 & 20000 & 122 & 9884 & 74 \\
\hline & Vehicle carrier & 9427900 & 229700 & 99300 & 14400 & 13200 & 475 & 961 & 56 \\
\hline & Cruise ship & 5004800 & 107200 & 43500 & 6700 & 6500 & 0 & 253 & 14 \\
\hline & Other & 3012500 & 57200 & 15000 & 3000 & 6000 & 0 & 4002 & 43 \\
\hline & Service vessel & 2036100 & 39200 & 8700 & 1900 & 3600 & 0 & 866 & 15 \\
\hline & Fishing vessel & 1381800 & 26000 & 7200 & 1300 & 2900 & 0 & 1829 & 33 \\
\hline & Passenger ferry & 576000 & 10400 & 3500 & 600 & 900 & 0 & 621 & 15 \\
\hline \multirow[t]{8}{*}{ GT } & $(\mathrm{GT}<4000 \mathrm{t})$ & 14496600 & 272700 & 72000 & 14000 & 25700 & 395 & 31770 & 359 \\
\hline & $(4000 \mathrm{t}<\mathrm{GT}<10000 \mathrm{t})$ & 15092900 & 330000 & 114800 & 18700 & 24500 & 758 & 4042 & 161 \\
\hline & $(10000 t<G T<20000 t)$ & 15018800 & 376000 & 146000 & 21800 & 24000 & 968 & 2814 & 100 \\
\hline & $(20000 \mathrm{t}<\mathrm{GT}<30000 \mathrm{t})$ & 18822100 & 478400 & 195800 & 29000 & 27400 & 1573 & 2668 & 95 \\
\hline & $(30000 \mathrm{t}<\mathrm{GT}<45000 \mathrm{t})$ & 16536800 & 436200 & 181000 & 26500 & 25200 & 1664 & 2548 & 68 \\
\hline & $(45000 \mathrm{t}<\mathrm{GT}<60000 \mathrm{t})$ & 10878200 & 289100 & 123400 & 18000 & 17100 & 1137 & 1060 & 37 \\
\hline & $(60000 \mathrm{t}<\mathrm{GT}<80000 \mathrm{t})$ & 10127000 & 278400 & 120500 & 17400 & 18500 & 1301 & 855 & 28 \\
\hline & $(\mathrm{GT}>80000 \mathrm{t})$ & 19749300 & 503100 & 254200 & 35700 & 34200 & 2745 & 1476 & 40 \\
\hline
\end{tabular}

\section{Results and discussion}

\subsection{Summaries of total emissions and their geographical distribution in Europe}

A compilation of computed emissions, payloads, numbers of ships, and distances travelled has been presented in Table 1. The geographical distribution of ship $\mathrm{CO}_{2}$ emissions and hotspots and are illustrated in Figs. 2 and 3. The results have been presented in terms of (i) IMO registered and unidentified ships, (ii) sea regions, (iii) top flag states, and (iv) ship types. The percentages of the total ship emissions in each of the sea regions for the selected pollutants have also been presented graphically in Fig. 4. The region denoted as "other" (that refers to other European sea areas) includes the western parts of the Black Sea, Canary Islands, Celtic Sea, Barents Sea and Northeast Atlantic Ocean (see Fig. 1).
The highest $\mathrm{CO}_{2}$ emissions are located along the busiest shipping lines near the coast of the Netherlands and in the English Channel, in the straits of Gibraltar, Sicily and Bosporus, and in the Danish Straits. In addition, there are localized high amounts of $\mathrm{CO}_{2}$ emissions near several major ports. These ports include, in particular, the ones in the Netherlands (e.g. Antwerp, Rotterdam, and Amsterdam), Gibraltar, St. Petersburg, and some ports in the UK, Germany, Italy, and Spain. The relative geographical distribution of the shipping emissions is similar also for the other modelled compounds, and those results have therefore not been presented here.

The international cargo traffic contributes significantly to the emissions at the most densely trafficked shipping lanes; a prominent example is the ship route in the Mediterranean Sea that extends from Suez Canal to Gibraltar. The route patterns of passenger traffic are different; these occur more frequently 


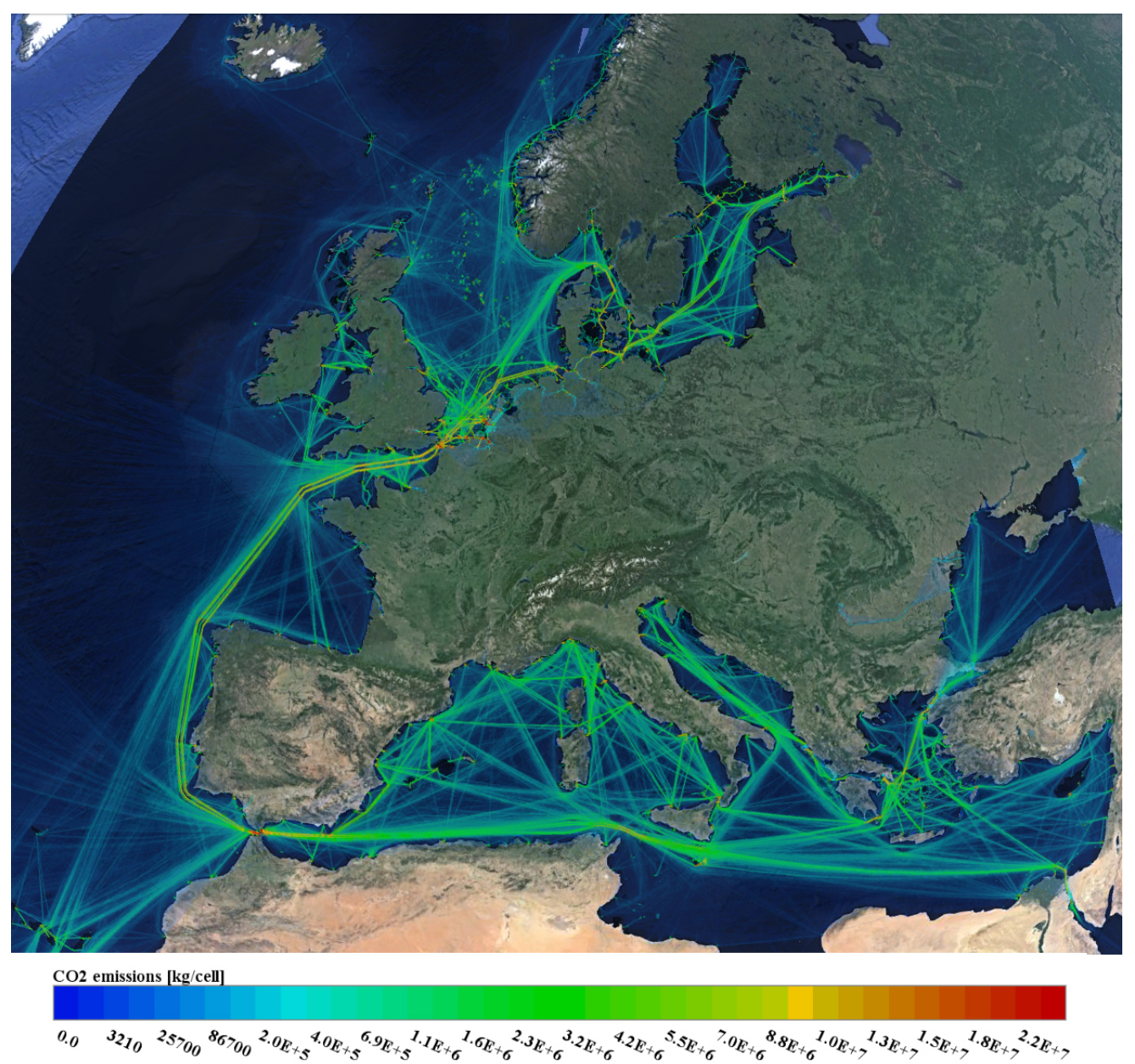

Figure 2. Predicted geographic distribution of shipping emissions of $\mathrm{CO}_{2}$ in Europe in 2011. The colour code indicates emissions in relative mass units per unit area.

via shorter routes. For example, there are a lot of routes between the islands in Greece and the mainland, and between Italy and the islands of Sardinia, Corsica, and Sicily. There is a dense network of shorter passenger vessel routes in numerous sea regions in the Mediterranean. The routes of cargo and passenger traffic intersect also in several regions of the Baltic Sea and the North Sea. For example, in the English Channel passenger traffic takes place mainly across the channel, whereas most of the cargo routes are aligned along the Channel.

We have also analysed the areas that have the highest $\mathrm{CO}_{2}$ shipping emissions in Europe. These areas were defined as circular domains with a radius of $10 \mathrm{~km}$. We have presented the results for 30 areas that had the highest estimated emissions. These domains are called in the following text as the emission hot spots. The results have been presented in Table 2 and in Fig. 3. The combined $\mathrm{CO}_{2}$ emissions of these 30 hotspot areas correspond to approximately $7 \%$ of total $\mathrm{CO}_{2}$ emitted by ships in Europe.
The area including the Netherlands and the English Channel has the highest density of these hot spots; there are in total 10 domains in these regions amongst the top 30 shipping $\mathrm{CO}_{2}$ hotspots in Europe. There are also hot spots at numerous locations in the Mediterranean, some in Germany, and a few in the Baltic Sea region. Harbour areas dominate the list of highest $\mathrm{CO}_{2}$ hotspots. Besides harbour locations, some shipping lanes and some major coastal cities are associated with very high $\mathrm{CO}_{2}$ emissions. Clearly, a major part of emissions in these coastal cities are also due to harbour activities. Several of the largest harbours in Europe reside in the Netherlands and along the English Channel.

In some sea regions, busy shipping traffic is focused in geographical bottlenecks with high $\mathrm{CO}_{2}$ emissions; prominent examples of these in southern Europe are the strait of Gibraltar, the channel between Malta and Sicily, and the Bosporus Strait. However, the emissions originated in the Bosporus Strait are not well represented in the data, as the data from the Turkish national AIS network were not available for this 


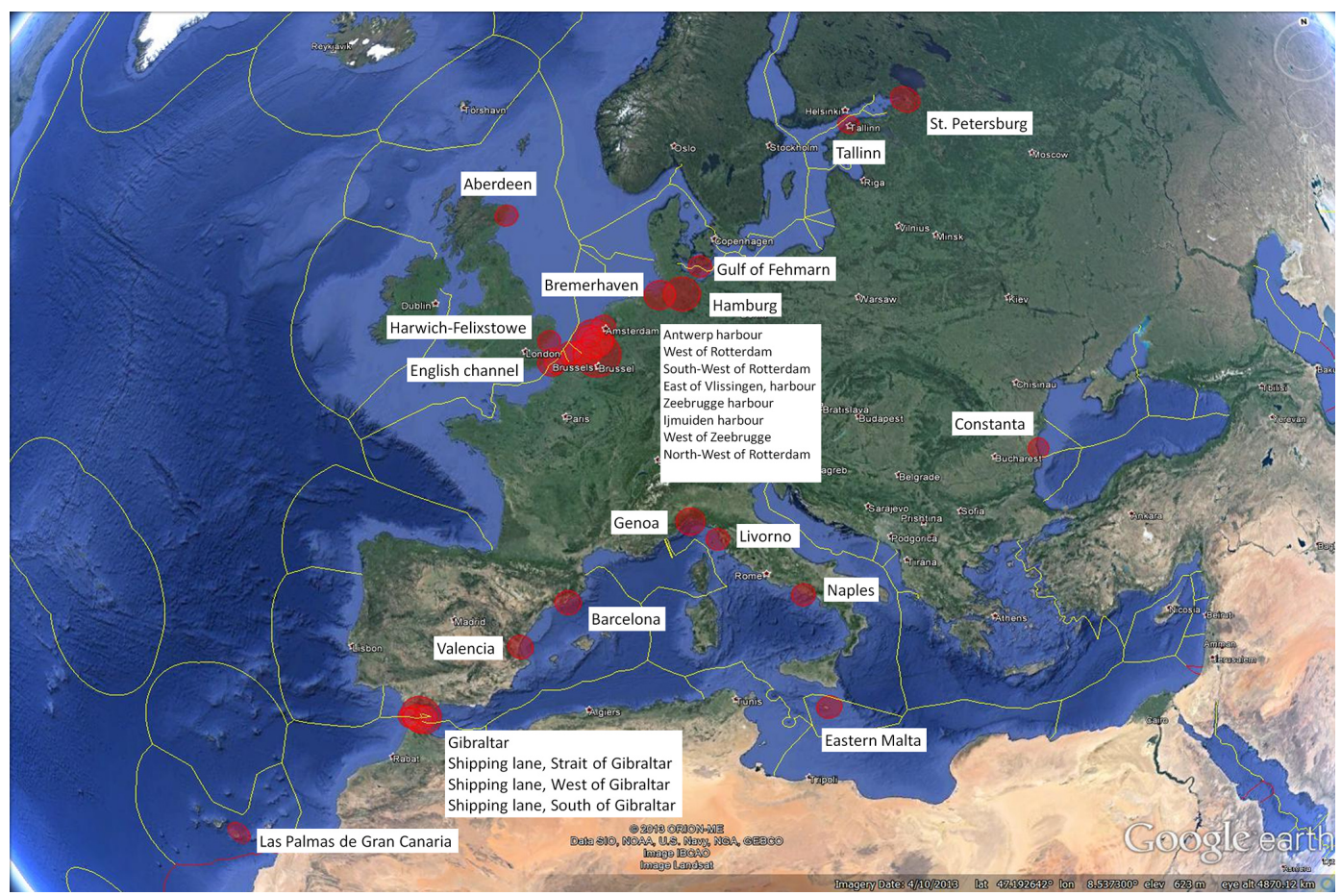

Figure 3. The 30 locations in which there were highest ship emissions of $\mathrm{CO}_{2}$ in Europe in 2011. The area of each circle is proportional to the annual $\mathrm{CO}_{2}$ emission.

study. The data from Greece and Romania include part of vessel activity from this area, but not a sufficient coverage.

Emissions of $\mathrm{CO}_{2}$ originated from Mediterranean shipping were found to be about $40 \%$ of the total $\mathrm{CO}_{2}$ emissions from shipping. Emissions from ships in the North Sea and the Baltic Sea constituted approximately one quarter and one eight of the total emissions of $\mathrm{CO}_{2}$ from shipping, respectively. The emissions of $\mathrm{NO}_{x}$ from the ships in the Mediterranean Sea (1 $229000 \mathrm{t}$, calculated as $\left.\mathrm{NO}_{2}\right)$ are almost as high as those in the Baltic Sea (329000t) and the North Sea $(649000 \mathrm{t})$ combined. The emissions of $\mathrm{NO}_{x}$ from other areas considered in this study are slightly higher than the contribution from the North Sea shipping. The share of the Mediterranean Sea traffic is even larger in case of the SOx emissions, compared with the corresponding emissions for $\mathrm{CO}_{2}$ and $\mathrm{NO}_{x}$.

The emissions originated from the other sea areas except for the three specifically mentioned three sea regions (Baltic Sea, North Sea and Mediterranean Sea) have also been reported in Table 1 and Fig. 4. These areas include the western parts of the Black Sea, Canary Islands, Celtic Sea, Barents Sea and Northeast Atlantic Ocean. The emissions from shipping in these other regions were estimated to produce almost one quarter of $\mathrm{CO}_{2}$; however, this value is probably an underestimation, as the coverage of AIS reception in remote sea areas, such as the Atlantic Ocean, is incomplete. It is also likely that inland shipping is only partially covered in our analysis.

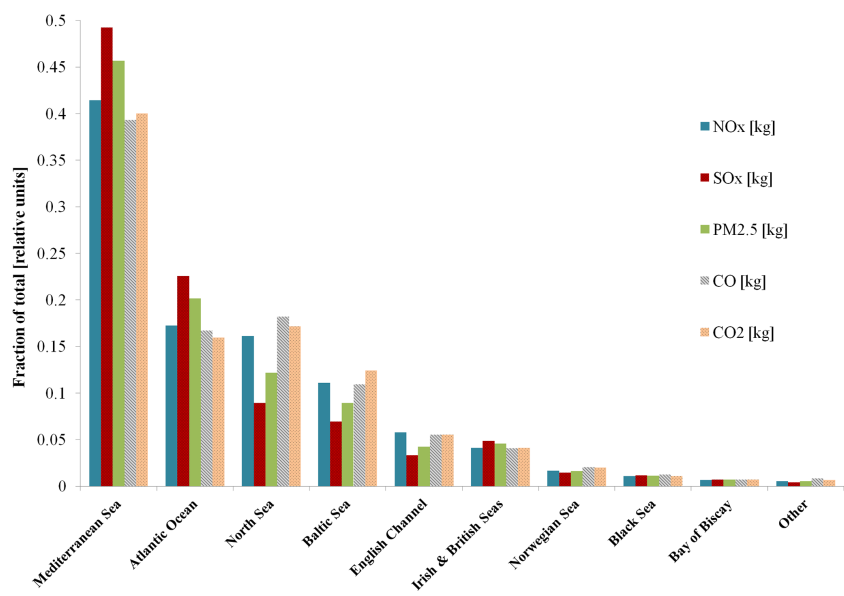

Figure 4. The fractions of shipping emissions for European sea regions in 2011.

These results have obvious policy implications. Reductions of ship exhaust emissions in areas with high emission levels and a surrounding dense population is likely to yield major health benefits (e.g. Corbett et al., 2007; USEPA, 2008; Bosch et al., 2009; Brandt et al., 2013; Jonson et al., 2015). However, policy changes for reducing shipping emissions may have significant cost impacts (e.g. Johansson et al., 2013; Kalli et al., 2013), which necessitates thorough assessments of both the costs and the benefits. The identified 
Table 2. The locations in European sea areas that contain the highest $\mathrm{CO}_{2}$ emissions within a circular area that has a radius of $10 \mathrm{~km}$.

\begin{tabular}{|c|c|c|c|c|c|}
\hline Rank & Description & $\begin{array}{r}\text { Latitude } \\
(\text { degrees, } \mathrm{N})\end{array}$ & $\begin{array}{r}\text { Longitude } \\
\text { (degrees, E) }\end{array}$ & $\begin{array}{r}\mathrm{CO}_{2}(r=10 \mathrm{~km}) \\
\left(10^{3} \mathrm{t}\right)\end{array}$ & $\begin{array}{r}\text { Fraction of total } \mathrm{CO}_{2} \\
(\%)\end{array}$ \\
\hline 1 & Antwerpen harbour & 51.3172 & 4.3066 & 786 & 0.61 \\
\hline 2 & Gibraltar harbour & 36.1037 & -5.3687 & 668 & 0.51 \\
\hline 3 & West of Rotterdam & 51.9735 & 4.1022 & 604 & 0.47 \\
\hline 4 & Hamburg & 53.5441 & 9.8937 & 471 & 0.36 \\
\hline 5 & St. Petersburg & 59.9202 & 30.1643 & 367 & 0.28 \\
\hline 6 & Shipping lane, Gulf of Gibraltar & 35.9396 & -5.5390 & 367 & 0.28 \\
\hline 7 & Southwest of Rotterdam & 51.8563 & 4.3406 & 352 & 0.27 \\
\hline 8 & Northwest of Bremerhaven & 53.5910 & 8.4629 & 348 & 0.27 \\
\hline 9 & Shipping lane, English channel & 51.0593 & 1.5470 & 304 & 0.23 \\
\hline 10 & Las Palmas de Gran Canaria harbour & 28.1571 & -15.3507 & 292 & 0.22 \\
\hline 11 & Genoa harbour & 44.3551 & 8.8717 & 289 & 0.22 \\
\hline 12 & East of Vlissingen, harbour & 51.4109 & 3.6933 & 281 & 0.22 \\
\hline 13 & Zeebrugge harbour & 51.3875 & 3.1142 & 261 & 0.20 \\
\hline 14 & Barcelona harbour & 41.3077 & 2.2284 & 242 & 0.19 \\
\hline 15 & Valencia harbour & 39.4089 & -0.2585 & 236 & 0.18 \\
\hline 16 & Eastern Malta & 35.8693 & 14.5951 & 233 & 0.18 \\
\hline 17 & Shipping lane,West of Gibraltar & 35.9162 & -5.7775 & 209 & 0.16 \\
\hline 18 & Shipping lane, South of Gibraltar & 36.0803 & -5.1302 & 205 & 0.16 \\
\hline 19 & Napoli habour & 40.7920 & 14.1863 & 201 & 0.16 \\
\hline 20 & Ijmuiden harbour & 52.4658 & 4.7495 & 201 & 0.15 \\
\hline 21 & West of Zeebrugge & 51.4344 & 2.6372 & 200 & 0.15 \\
\hline 22 & Northwest of Rotterdam & 52.0907 & 3.8296 & 196 & 0.15 \\
\hline 23 & Aberdeen harbout & 57.2010 & -1.9959 & 195 & 0.15 \\
\hline 24 & Gulf of Fehmarn & 54.5990 & 11.2905 & 193 & 0.15 \\
\hline 25 & Shipping lane, English channel & 51.0593 & 1.78557 & 193 & 0.15 \\
\hline 26 & Constanta harbour & 44.1207 & 28.7334 & 191 & 0.15 \\
\hline 27 & Shipping lane, west of Gibraltar & 35.9162 & -6.0160 & 187 & 0.14 \\
\hline 28 & Livorno harbour & 43.5346 & 10.2004 & 183 & 0.14 \\
\hline 29 & Tallinn harbour & 59.5217 & 24.7134 & 181 & 0.14 \\
\hline 30 & Harwich-Felixstowe harbour & 51.9266 & 1.3426 & 179 & 0.14 \\
\hline
\end{tabular}

emission hot spots, especially those which are in the vicinity of major cities, are prime candidates for enhanced emission control measures. The low fuel sulphur requirement of the EU directive has already addressed some aspects of this issue.

\subsection{Analysis of emissions in terms of the flag state and the ship type}

The AIS signals include a Maritime Mobile Service Identity (MMSI) code that contains information that specifies the flag state of the ship. We have selected 16 flag states that had the highest total fuel consumption in Europe in 2011, and evaluated their annual statistics of the numbers of ships, payload, and the emissions of three pollutants. The results of this analysis are included in Fig. 5. The emissions have been presented as fractions (\%) of the total emissions in the European sea areas in Fig. 5.

The emissions were largest for the Liberian and second largest for the Italian fleet. The UK, Malta, Bahamas, Norway, and the Netherlands also have had ma- jor fleets. In addition to major European states, such as Italy, UK, Norway, the Netherlands, Greece, Germany, etc., major fleets have also sailed under the flags of relatively smaller states, such as Liberia, Malta, Bahamas, Marshall Islands, etc. The flags of convenience allow open vessel registration regardless of the owner's nationality (ITF, http://www.itfglobal.org/en/transport-sectors/ seafarers/in-focus/flags-of-convenience-campaign/), which is in contrast with national ship registries. The states among the top 16 fuel consumers with the flags of convenience are Panama, Cyprus, Antigua and Barbuda, Marshall Islands, Bahamas, Malta, and Liberia. The $\mathrm{CO}_{2}$ emission shares of vessels in open registries are responsible for $25 \%$, European vessels contribute $55 \%$ and vessels with some other flag contribute $20 \%$ of the total $\mathrm{CO}_{2}$ emissions. The emissions under flags of convenience are distributed throughout the all EU sea regions, whereas the emissions of vessels of some countries (for example Sweden, France, and Finland) mostly occur close to the national coastlines or in the nearby sea areas. 


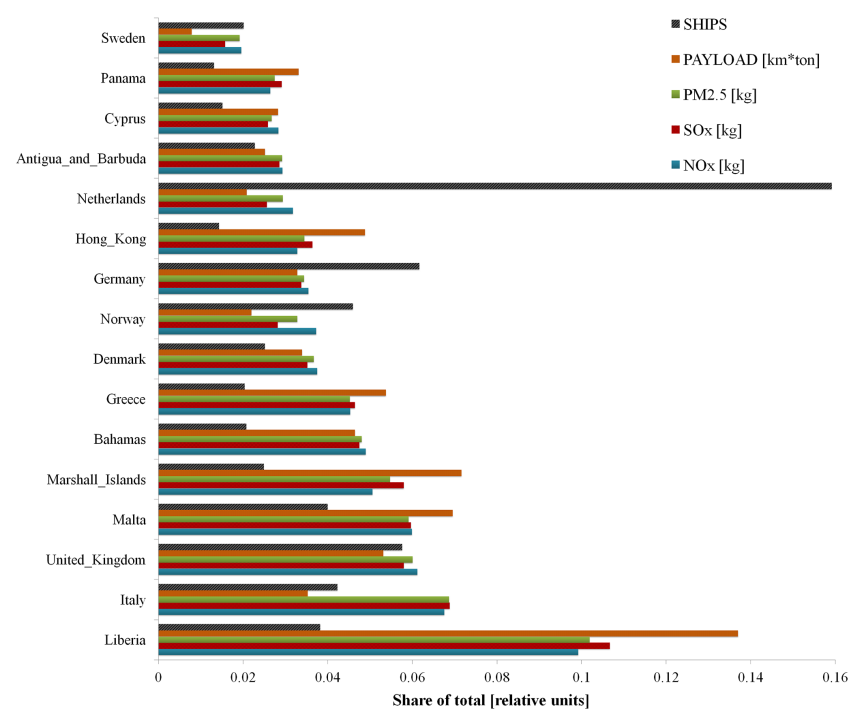

Figure 5. Relative contributions of various flag states to selected emissions, the numbers of ships and cargo payload in Europe in 2011. We have selected 20 states that had the highest emissions of $\mathrm{CO}_{2}$. These states have been presented in terms of the emissions of $\mathrm{CO}_{2}$; the lowest entry (Liberia) in the figure had the highest emissions.

We have allocated the emissions to IMO registered (referred here also as "large") and unidentified (referred to as "small") ships in Table 1, as the IMO registered ships constitute most of the commercial marine traffic. According to the values in Table 1 , the contribution of unidentified vessels is only $1.7 \%$ of the total $\mathrm{CO}_{2}$ emissions, although the number of such small vessels is over $41 \%$ of all vessels. The unidentified ships travel $7 \%$ of the distances travelled by all vessels. For some countries, such as the Netherlands, Germany, France, and Sweden, the share of large vessels is less than one third of the total number of ships. This may indicate the different practices in including the small vessel movements in overall traffic image of various countries. It is very likely that small vessel traffic is underestimated by AIS, because for these vessels AIS is voluntary, in contrast to the requirements for large vessels. In this context, the Dutch fleet is an extreme case, in which only $13 \%$ of 7530 vessels are considered large. In the Dutch case, the share of $\mathrm{CO}_{2}$ emitted by small vessels is $43 \%$, which is the largest fraction for all of the studied fleets. The large number of small vessels in the AIS data in the case of the Dutch fleet can be explained by the fact that the use of the AIS equipment is compulsory in the non-recreational inland vessels in the Netherlands. In Finland, there are over 190000 motor boats (Trafi, 2014) and 525 Finnish vessels were picked up by AIS in Europe. Clearly, the representation of small vessel traffic substantially varies between countries; their activities are incompletely represented in the AIS signals.

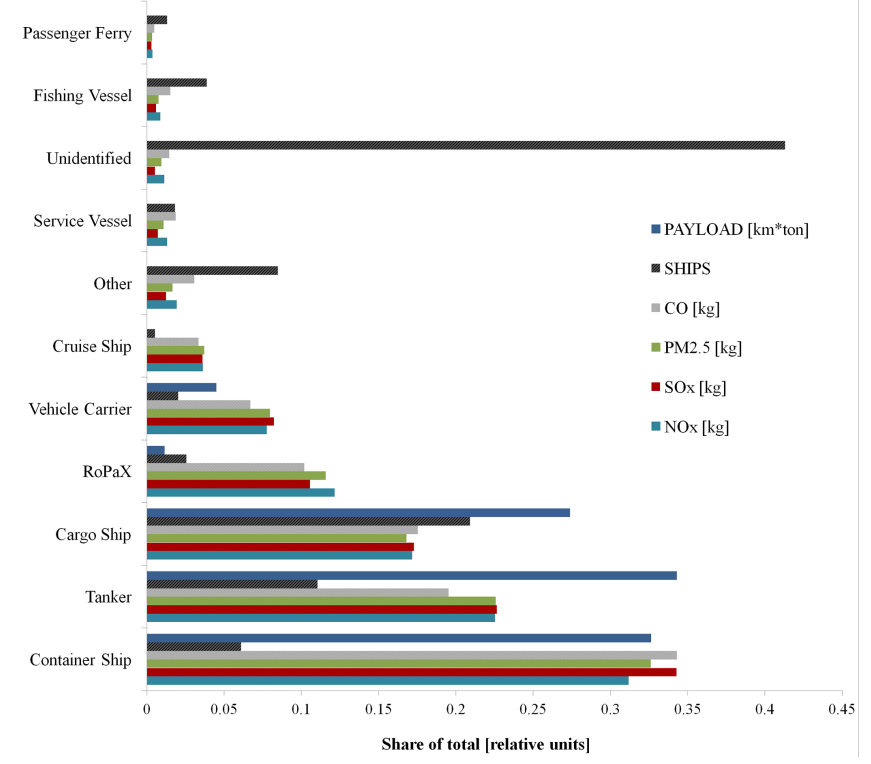

Figure 6. The fractions of European shipping emissions and payload, classified in terms of the ship types, in 2011.

The descriptions of the technical details for small vessels in the emission inventory are limited. These are significantly less accurate than the corresponding descriptions for large vessels, for which the engine setup and technical data are readily available. Model results for the fuel consumption of small vessels are further complicated by an incomplete inclusion of the activities of small vessels; a fraction of the small vessels do not carry AIS equipment on board.

The shares of emissions for various ship types have been presented in Fig. 6. A comparison of $\mathrm{CO}_{2}$ emissions and payload reflects the energy efficiency of various ship types. We used the approach described by Buhaug et al. (2009). The unit emissions (the mass of $\mathrm{CO}_{2}$ emitted, divided by transport work) are lowest for the tanker class $\left(7.3 \mathrm{~g} \mathrm{t}^{-1} \mathrm{~km}^{-1}\right)$, slightly higher for container $\left(10.2 \mathrm{~g} \mathrm{t}^{-1} \mathrm{~km}^{-1}\right)$ and cargo vessels $\left(10 \mathrm{~g} \mathrm{t}^{-1} \mathrm{~km}^{-1}\right)$, and significantly higher for passenger traffic $\left(175 \mathrm{~g} \mathrm{t}^{-1} \mathrm{~km}^{-1}\right)$. However, the values for passenger traffic are not directly comparable, as the above-mentioned transport work of passenger traffic has been calculated as a function of cargo capacity, which does not take the number of passengers into account. There are large variations of unit emissions between various vessels in the cargo class, as this class includes both dry bulk and palletized cargo vessels, for which there are large differences in the use of their cargo carrying capacity.

\subsection{Seasonal variation of the emissions}

There were clear seasonal variations in the emissions of all pollutants; the variations in case of $\mathrm{CO}_{2}$ have been presented in Fig. 7. For example, the emissions of $\mathrm{CO}_{2}$ in June are $30 \%$ larger than the corresponding values in January. During the 


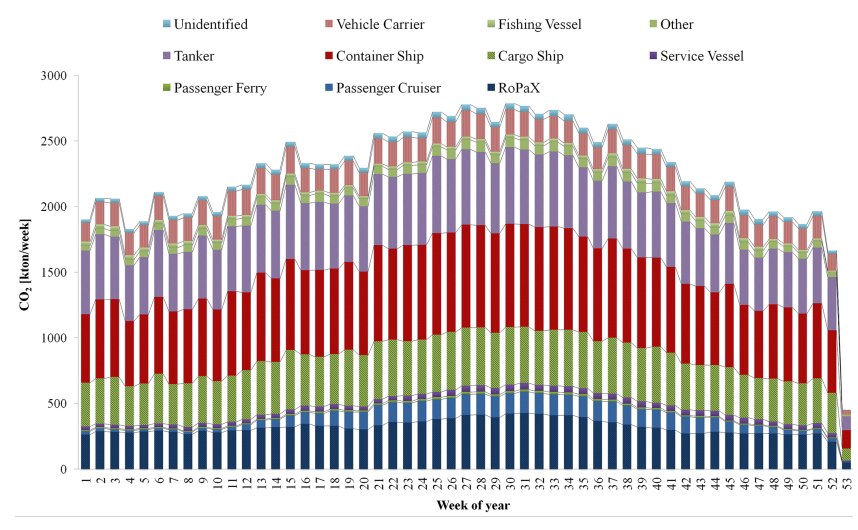

Figure 7. Seasonal variation of the shipping emissions of $\mathrm{CO}_{2}$ in the European sea regions in 2011, classified in terms of various vessel categories.

summer months (June, July, and August), both the numbers of passenger vessels and small vessels is the largest, especially in the Mediterranean Sea. This is mainly caused by the increased recreational travel; in summer the number of small vessels is at a maximum in all sea areas. The emissions of container ships are also higher in the summer than winter, but the activities of tankers and cargo ships exhibit no substantial seasonal dependency. Recently, Ialongo et al. (2014) used satellite-based OMI $\mathrm{NO}_{x}$ observations to track the annual variability of $\mathrm{NO}_{x}$ emissions from Baltic Sea shipping. Ialongo et al. demonstrated a decrease in satellite-observed $\mathrm{NO}_{x}$ similar to Jalkanen et al. (2014). Although the emissions cannot be directly compared with observations of atmospheric columns of $\mathrm{NO}_{x}$, decrease of $\mathrm{NO}_{x}$ was observed in both data sets which coincide with the economic downturn during 2008-2009.

A disaggregated compilation of vessel types and their operational features has been presented in Table 3. The five more general level categories (cargo, container, tanker, passenger, and other) have been divided into more detailed categories. The division of vessel activity to operational modes (cruising, maneuvering, and hotelling) has not been predetermined; it has been defined by vessel activity data. Based on AIS data, it is possible to determine these explicitly, which will significantly decrease the large uncertainties that have previously been associated with vessel activities.

The shares of fuel used by the main engines have also been presented in Table 3, these have also been evaluated by the model. The amounts of fuel used in main and auxiliary engines depend not only on vessel specifics, but also its operational profile. However, there is a major uncertainty in the predictions of the fuel consumption of the auxiliary engine, as the use of an auxiliary engine varies greatly, even for ships of the same type. The use of auxiliary power cannot be determined from tank tests of ship resistance, unlike the power needed for propulsion, for which various theories exist for performance prediction. In this study, we have used the methodology presented previously (Jalkanen et al., 2009, 2012; Johansson et al., 2013). This method combines the information on cargo capacity, auxiliary engine power profiles, main and auxiliary engine setup and power transmission method. However, there are also other modelling approaches, which are based on extensive vessel boarding programs (Starcrest, 2013), local knowledge, and pre-assigned contributions (Dalsøren et al., 2009). The share of auxiliary engine fuel consumption from total consumption is very high for service vessels and tugboats. This is consistent with the 2nd IMO GHG report by Buhaug et al. (2009); however, the contribution of these vessels to the total fuel consumption or $\mathrm{CO}_{2}$ emission from shipping in the study area is small, less than $2.5 \%$.

\subsection{Comparison of the predictions of various emission inventories}

The comparison of the numerical results of various European-scale emission inventories can be challenging, as pointed out, e.g. by EEA (2013). The main reasons for this are that the methodologies and various modelling selections used for evaluating shipping emissions vary substantially in various published studies. E.g. the various studies may define differently the geographical domain, and some studies address only international ship traffic.

The current work reports emissions for the year 2011. Significant reductions were therefore in force regarding the sulphur content of marine fuel in the North Sea and the Baltic Sea area, as well as the requirement for low sulphur fuel in EU harbour areas. The effects of these regulations were included in the current work, and it is therefore not possible to directly compare the predicted $\mathrm{SO}_{x}$ and $\mathrm{PM}_{2.5}$ emissions with the corresponding values during previous years. Changes in international regulations also concern $\mathrm{NO}_{x}$, but to a lesser extent, as the IMO Tier II NO$x$ limits for marine diesel engines affect all engines built since 1 January 2011. The ships constructed after this date will have to conform to Tier II $\mathrm{NO}_{x}$ requirements $\left(15 \%\right.$ less $\mathrm{NO}_{x}$ produced when compared with Tier I engines), but such new ships constitute only $3 \%$ of the fleet of IMO registered vessels in this study. Significant policy changes are expected to be implemented in 2015, regarding the sulphur content of marine fuel.

The emissions of $\mathrm{NO}_{x}$ for the Mediterranean Sea reported in this work are lower than in the EMEP inventory; qualitatively the same conclusion was reported by Marmer et al. (2009). Marmer et al. (2009) also concluded that their methodology yielded lower $\mathrm{SO}_{x}$ emissions than the corresponding EMEP values. The prediction of the STEAM inventory for the Mediterranean shipping in the case of $\mathrm{NO}_{x}$ is about $80 \%$ of the corresponding value in the EMEP inventory, allowing for the update in 2015 of the EMEP emissions in 2011 (EMEP, http://www.ceip.at/ms/ceip_home1/ceip_ home/webdab_emepdatabase/emissions_emepmodels/). Vinken et al. (2014) used satellite observations of $\mathrm{NO}_{x}$ from 
Table 3. Summary of average operational features of some selected ship types. The first column indicates the aggregated ship type, whereas the second column contains a more detailed description of vessel type. The time spent in each operation mode (cruising, maneuvering, hotelling) is indicated by the next three columns as percentages. "ME of Fuel" refers to the fraction of fuel used in main engines from total fuel consumption. Cruising speed indicates average cruising speed observed in AIS data. The last column on the right-hand side indicates the significance of contribution to overall $\mathrm{CO}_{2}$ emissions. These ship types are responsible for over $98 \%$ of total $\mathrm{CO}_{2}$ emitted.

\begin{tabular}{llrrrrrrrrr}
\hline Ship type & $\begin{array}{l}\text { Disaggregated } \\
\text { ship type }\end{array}$ & $\begin{array}{r}\text { Cruise } \\
(\%)\end{array}$ & $\begin{array}{r}\text { Man. } \\
(\%)\end{array}$ & $\begin{array}{r}\text { Hotel } \\
(\%)\end{array}$ & $\begin{array}{r}\text { Build } \\
\text { year }\end{array}$ & $\begin{array}{r}\text { ME Fuel } \\
(\%)\end{array}$ & $\begin{array}{r}\text { Design } \\
\text { speed }\end{array}$ & $\begin{array}{r}\text { Ships } \\
\text { Cruising } \\
\text { speed }\end{array}$ & $\begin{array}{r}\text { of all CO }_{2} \\
(\%)\end{array}$ \\
\hline Container ship & Container ship & $59 \%$ & $3 \%$ & $38 \%$ & 2002 & 75 & 21.7 & 2373 & 15.9 & 27.6 \\
Container ship & Reefer & $48 \%$ & $4 \%$ & $48 \%$ & 1991 & 72 & 18.2 & 500 & 14.6 & 1.6 \\
RoPaX & RoPaX & $40 \%$ & $5 \%$ & $56 \%$ & 1990 & 75 & 19.0 & 1207 & 13.6 & 14.5 \\
Cargo ship & Bulk carrier & $59 \%$ & $2 \%$ & $39 \%$ & 1999 & 85 & 14.2 & 4008 & 12.1 & 9.0 \\
Cargo ship & General cargo & $51 \%$ & $4 \%$ & $45 \%$ & 1991 & 78 & 12.5 & 5855 & 9.9 & 8.2 \\
Tanker & Chemical tanker & $53 \%$ & $3 \%$ & $44 \%$ & 2003 & 71 & 14.0 & 2385 & 12.0 & 8.8 \\
Tanker & Crude-oil tanker & $51 \%$ & $5 \%$ & $44 \%$ & 2003 & 76 & 14.6 & 1216 & 12.0 & 6.9 \\
Tanker & LNG tanker & $71 \%$ & $4 \%$ & $25 \%$ & 2002 & 82 & 19.2 & 219 & 14.7 & 2.7 \\
Tanker & Product tanker & $40 \%$ & $6 \%$ & $54 \%$ & 1996 & 59 & 12.9 & 949 & 10.4 & 2.3 \\
Vehicle carrier & RoRo cargo & $52 \%$ & $2 \%$ & $45 \%$ & 1991 & 78 & 17.1 & 448 & 13.5 & 4.7 \\
Vehicle carrier & Vehicle carrier & $68 \%$ & $3 \%$ & $29 \%$ & 2002 & 84 & 19.5 & 510 & 15.6 & 3.4 \\
Cruise ship & Cruise ship & $53 \%$ & $3 \%$ & $44 \%$ & 1989 & 73 & 18.8 & 251 & 13.5 & 4.3 \\
Service vessel & Service vessel & $20 \%$ & $14 \%$ & $67 \%$ & 1997 & 44 & 13.7 & 866 & 9.4 & 1.7 \\
Fishing vessel & Fishing vessel & $24 \%$ & $20 \%$ & $56 \%$ & 1988 & 52 & 12.5 & 1826 & 8.9 & 1.2 \\
Other & Tugboat & $15 \%$ & $8 \%$ & $77 \%$ & 1994 & 47 & 12.9 & 1588 & 8.3 & 0.7 \\
Other & Dredger & $19 \%$ & $12 \%$ & $69 \%$ & 1983 & 55 & 10.5 & 377 & 8.1 & 0.5 \\
\hline
\end{tabular}

the OMI instrument to constrain top-down emissions from ships. The study area of this study (defined by AIS coverage illustrated in Fig. 1) and Vinken et al. (2014) are the same (N, W, S boundaries are same), except that the domain used by Vinken et al. (2014) extends further to the East $\left(50^{\circ} \mathrm{E}\right)$; neither of these assessments includes the trans-Atlantic ship traffic.

The reported total $\mathrm{NO}_{x}$ emission for all European sea areas in our study is 2.96 million t, which corresponds to 0.9 million $\mathrm{t}$ of reduced nitrogen $(\mathrm{N})$. This is close to the corresponding value reported by Vinken et al. (2014), their estimate for European shipping emissions was 1.0 million $\mathrm{t}$ of reduced nitrogen for the year 2006. Unfortunately, AIS data from 20052006 for all European sea areas are not available since at the time AIS had just been deployed as a navigational aid and fleet-wide adoption of AIS was in progress. The difference between the $\mathrm{NO}_{x}$ emissions of the STEAM and EMEP inventories in the Baltic Sea shipping is $18 \%$ (the emission values of STEAM is higher). However, the comparison with Vinken et al. (2014) is challenging for the Baltic Sea, as Vinken et al. (2014) report only emissions along the major ship tracks, which are not representative of the emissions in the whole of the Baltic Sea area.

The annual $\mathrm{SO}_{x}$ emissions reported in this study for various sea regions are 84000,148000 , and $595000 \mathrm{t}$ for the Baltic Sea, North Sea/English Channel, and the Mediterranean, respectively. The corresponding $\mathrm{SO}_{x}$ emissions of the EMEP inventory for the above-mentioned sea areas are 69000,163000 , and $978000 \mathrm{t}$, taking into account the update of the EMEP inventory in 2015. For the Baltic Sea and the North Sea, the inventories are approximately in agreement (their differences are 22 and $10 \%$ ), but there is a larger difference in the predicted emissions of SOx in the Mediterranean Sea. The $\mathrm{SO}_{x}$ emissions predicted in this study for the Mediterranean are about two thirds of the corresponding values in the EMEP inventory.

The reasons for such major differences in the predictions of these two inventories could be caused, for example, by the neglect of the impacts of relevant legislation, such as the EU sulphur directive (EU, 2012). This directive limits the sulphur content of marine fuels to $0.1 \%$ (by mass) in harbour areas and to $1.5 \%$ (by mass) for passenger vessels on a regular schedule. It is possible that not all passenger ships comply with the requirement of $1.5 \%$ fuel sulphur content, as assumed in the STEAM model. However, a possible noncompliance by a fairly small fraction of ships would explain only a minor portion of the differences between the STEAM and EMEP inventories. More information on the compliance with EU regulations can be obtained either during Port State Control checks, or via relevant compliance monitoring schemes (Balzani et al., 2014; Berg et al., 2012; Beecken et al., 2014, 2015; Pirjola et al., 2014).

Plotting the EMEP time series of $\mathrm{SO}_{x}$ and $\mathrm{NO}_{x}$ for the shipping in the Mediterranean indicate that the $\mathrm{NO}_{x}$ and $\mathrm{SO}_{x}$ emissions decreased in a similar way during 2007-2010, probably reflecting the overall decreases in both shipping and economic activity. However, between 2009 and 2010, the $\mathrm{SO}_{x}$ emissions in EMEP inventories increased by more than $6 \%$, whereas the corresponding $\mathrm{NO}_{x}$ emissions from ships increased only by $1.4 \%$. At the same time, the EU sulphur 
directive came into force in January 2010, with requirements for the reduction of marine fuel sulphur content. This would have been expected to decrease the $\mathrm{SO}_{x}$ emissions from the shipping in the Mediterranean, instead of increasing them. However, in 2010 the new $\mathrm{NO}_{x}$ limits (IMO Tier II) were implemented for vessels constructed since 2010, but in 2011 only $3 \%$ of the fleet were new ships. Calculating backwards from $\mathrm{SO}_{2}$ values of Table 1, the average fuel sulphur content (denoted here by $S$ ) of some major ship types yields $1.9 \% \mathrm{~S}$ for container ships, $1.6 \% S$ for tankers, $1.2 \% S$ for RoPax and $1.4 \% S$ for cruise vessels. It should be noted that these values represent a combination of $\mathrm{SO}_{x}$ from both main and auxiliary engines, which may use fuels with different fuel sulphur content. Also, these averages include contributions from vessels sailing both the SECA and the non-SECA's. The differences in the STEAM and EMEP inventories warrant further study; these differences should also be examined using dispersion modelling and air quality measurements.

It is not possible to perform a similar satellite-based comparison for $\mathrm{SO}_{x}$, due to the technical limitations of currently available satellite instruments; these cannot accurately determine ship emitted $\mathrm{SO}_{x}$ near the sea surface. Such instruments can detect stationary $\mathrm{SO}_{2}$ sources that have an emission higher than approximately $70 \mathrm{kt}$ (Fioletov et al., 2013); however, this value is too high for the shipping lanes in Europe.

The inventory of Cofala et al. (2007) includes an estimate for ship $\mathrm{CO}_{2}$ emissions, which is based on the same methodology as the EMEP inventories. According to Cofala et al. (2007), the predicted $\mathrm{CO}_{2}$ emission in 2010 from ships in the Mediterranean is approximately 76 million $\mathrm{t}(\mathrm{ob}-$ tained by a linear interpolation between the values in 2000 and 2020), whereas in this work, the Mediterranean shipping was responsible for 48 million $\mathrm{t}$ of $\mathrm{CO}_{2}$ emitted.

The differences in $\mathrm{PM}_{2.5}$ emissions between this work and Cofala et al. (2007) in all sea areas are less than 20\%. A large variation could be expected in the $\mathrm{PM}_{2.5}$ emissions predicted by the various methods, due to the substantial variability of experimentally determined emission factors and the differences in $\mathrm{PM}_{2.5}$ sampling methods (e.g. Jalkanen et al., 2012). Clearly, the $\mathrm{PM}_{2.5}$ emissions are associated with the $\mathrm{SO}_{x}$ emissions and the sulphur content of the fuel, as $\mathrm{SO}_{4}$ is one of the main constituents of atmospheric $\mathrm{PM}_{2.5}$.

The range of European shipping emissions of $\mathrm{CO}_{2}$ reported in the review by EEA (2013) is 71-153 million $t$ (for various years between 2000-2009), based on the work of EEA (2013), Cofala et al. (2007), Whall et al. (2002), Schrooten et al. (2009) and Campling et al. (2012); the estimate of the present study is at the higher end of this range. Similarly, in case of $\mathrm{NO}_{x}$ emissions, the range of values in various inventories reviewed by EEA (2013) is 1.7-3.6 million t whereas this study evaluated the European emissions from shipping in 2011 to be 2.94 million t, calculated as $\mathrm{NO}_{2}$. However, in case of $\mathrm{NO}_{x}$ the inclusion of variability in assumptions of technology development (Tier I, II, inclusion of $\mathrm{NO}_{x}$ abatement, $\mathrm{NO}_{x}$ emission factor rpm dependency) of marine engines can have a large impact on overall $\mathrm{NO}_{x}$ results of various inventories, especially if ship emissions from different years are compared.

\section{Conclusions}

The comparison of emitted pollutants with existing ship emission inventories revealed that there are some differences between the estimates of the various inventories for the emissions of ships sailing the Mediterranean Sea, whereas the results were better in agreement for the North Sea and the Baltic Sea regions. The $\mathrm{NO}_{x}, \mathrm{SO}_{x}$, and $\mathrm{CO}$ emissions evaluated in this study for the Mediterranean Sea were 18, 39, and $49 \%$ lower than the corresponding values in the EMEP and IIASA inventories. The $\mathrm{PM}_{2.5}$ emissions from the STEAM inventory were $24 \%$ lower than indicated by the EMEP emission inventory. Satellite observations using the Ozone Monitoring Instrument (OMI) also indicated smaller annual emissions of $\mathrm{NO}_{x}$ in the Mediterranean, compared with the predictions of the EMEP inventory. These differences should be investigated further with a longer ship emission time series, which takes into account the relevant changes of the environmental legislation. From a technical point of view, it is feasible to have annual updates of bottom-up ship emission inventories.

Further research is required including emission modelling in combination with consecutive chemical transport modelling, comparisons with measured atmospheric concentrations of pollutants and source apportionment. The reasons for these deviations between different emission inventories should be investigated further and confirmed with independent experimental data sets, as these can have significant policy implications concerning health and environmental impact assessments within the transport sector. A logical step would be to include chemical transport modelling and comparisons with air quality measurements especially at coastal stations to determine whether the predicted $\mathrm{NO}_{x}$ and $\mathrm{SO}_{x}$ concentrations are in an agreement with the measurements.

Despite the wide geographical extent, the ship emission data can also be segmented in terms of the various properties of vessel categories or individual vessels. This makes it possible to classify the emissions using several criteria. The disaggregation of ship emissions into individual vessels on a fine temporal resolution also allows fine resolution air quality and health impact assessment studies. A specific advantage of an inventory based on individual vessel data is that it facilitates comparisons with experimental stack measurements.

According to this study, the vessels carrying an EU flag were responsible for $55 \%$ of $\mathrm{CO}_{2}$ emissions in the $\mathrm{EU}$, whereas the states with flags of convenience and other states constitute the remaining share. The $\mathrm{CO}_{2}$ hotspot mapping indicate that the English Channel constitutes a large source of 
ship emitted $\mathrm{CO}_{2}$, both from harbour areas and densely trafficked shipping lanes.

The emissions from ships have a clear seasonal variation; the emission maximum occurs during the summer months. This concerns especially passenger traffic, but also containerships have the same seasonal pattern. However, the emissions originated from oil tankers and other cargo ships do not have a clear seasonality. Temporal variation of ship emissions has mostly been neglected in previous emission inventories, due to inherent limitations of the activity data used as a basis for these inventories. Seasonal variations can be of the order of $30 \%$; these features should therefore be included in emission and health impact assessments.

The current work also facilitates studies of ship energy efficiency, as all emissions and fuel data are generated on the ship level. There were substantial differences between fuel burned and transport work carried out by various ship types. The unit emissions were the lowest for the oil tankers and largest for passenger vessels. However, the description of transport work of passenger vessels currently considers cargo operations and does not completely cover passenger cargoes.

\section{Data availability}

The gridded emission data sets of this work can be made available for further research upon request to the authors.

Acknowledgements. This study was made possible as a result of cooperation with the European Maritime Safety Agency and the Norwegian Coastal Administration. We would like to thank both agencies for making the relevant AIS data sets available for this work. We are also grateful for financial support of the European Space Agency (Samba project), FP7 project TRANSPHORM and the Academy of Finland (APTA project). This work is partly based on the material supplied by IHS Fairplay.

Edited by: W. Birmili

\section{References}

Balzani Lööv, J. M., Alfoldy, B., Gast, L. F. L., Hjorth, J., Lagler, F., Mellqvist, J., Beecken, J., Berg, N., Duyzer, J., Westrate, H., Swart, D. P. J., Berkhout, A. J. C., Jalkanen, J.-P., Prata, A. J., van der Hoff, G. R., and Borowiak, A.: Field test of available methods to measure remotely $\mathrm{SO}_{x}$ and $\mathrm{NO}_{x}$ emissions from ships, Atmos. Meas. Tech., 7, 2597-2613, doi:10.5194/amt-7-2597-2014, 2014.

Beecken, J., Mellqvist, J., Salo, K., Ekholm, J., and Jalkanen, J.P.: Airborne emission measurements of $\mathrm{SO}_{2}, \mathrm{NO}_{x}$ and particles from individual ships using a sniffer technique, Atmos. Meas. Tech., 7, 1957-1968, doi:10.5194/amt-7-1957-2014, 2014.

Beecken, J., Mellqvist, J., Salo, K., Ekholm, J., Jalkanen, J.-P., Johansson, L., Litvinenko, V., Volodin, K., and Frank-Kamenetsky, D. A.: Emission factors of $\mathrm{SO}_{2}, \mathrm{NO}_{x}$ and particles from ships in Neva Bay from ground-based and helicopter-borne measurements and AIS-based modeling, Atmos. Chem. Phys., 15, 52295241, doi:10.5194/acp-15-5229-2015, 2015.

Berg, N., Mellqvist, J., Jalkanen, J.-P., and Balzani, J.: Ship emissions of $\mathrm{SO}_{2}$ and $\mathrm{NO}_{2}$ : DOAS measurements from airborne platforms, Atmos. Meas. Tech., 5, 1085-1098, doi:10.5194/amt-51085-2012, 2012.

Bosch, P., Coenen, P., Fridell, E., Åström, S., Palmer, T., and Holland, M.: Cost Benefit Analysis to support the impact assessment accompanying the revision of Directive 1999/32/EC on the sulphur content of certain liquid fuels, AEA Technology, European Commission reports ENV.C.5/FRA/2006/0071, Harwell, Didcot OX, UK, 2009.

Brandt, J., Silver, J. D., Christensen, J. H., Andersen, M. S., Bønløkke, J. H., Sigsgaard, T., Geels, C., Gross, A., Hansen, A. B., Hansen, K. M., Hedegaard, G. B., Kaas, E., and Frohn, L. M.: Assessment of past, present and future health-cost externalities of air pollution in Europe and the contribution from international ship traffic using the EVA model system, Atmos. Chem. Phys., 13, 7747-7764, doi:10.5194/acp-13-7747-2013, 2013.

Buhaug, Ø., Corbett, J. J., Endresen, Ø., Eyring, V., Faber, J., Hanayama, S., Lee, D. S., Lee, D., Lindstad, H., Markowska, A. Z., Mjelde, A., Nelissen, D., Nilsen, J., Palsson, C., Winebrake, J. J., Wu, W.-Q., and Yoshida, K.: Second IMO GHG study, International Maritime Organization (IMO), London, UK, 2009.

Campling, P., Janssen, L., and Vanherle, K.: Specific evaluation of emissions from shipping including assessment for the establishment of possible new emission control areas in European Seas, VITO, Mol, Belgium, 2012.

Cofala, J., Amann, M., Heyes, C., Wagner, F., Klimont, Z., Posch, M., Schöpp, W., Tarasson, L., Jonson, J. E., Whall, C., and Stavrakaki, A.: Analysis of Policy Measures to Reduce Ship Emissions in the Context of the Revision of the National Emissions Ceilings Directive - Final Report. Contract number 070501/2005/419589/MAR/C1, International Institute for Applied Systems Analysis, Vienna, Austria, 2007.

Corbett, J. J., Winebrake, J. J., Green, E. H., Kasiblathe, P., Eyring, V., and Lauer, A.: Mortality from Ship Emissions: A Global Assessment, Environ. Sci. Technol., 41, 8512-8518, 2007.

Dalsøren, S. B., Eide, M. S., Endresen, Ø., Mjelde, A., Gravir, G., and Isaksen, I. S. A.: Update on emissions and environmental impacts from the international fleet of ships: the contribution from major ship types and ports, Atmos. Chem. Phys., 9, 2171-2194, doi:10.5194/acp-9-2171-2009, 2009.

EEA: The impact of international shipping on European air quality and climate forcing, EEA Technical report No 4/2013, Copenhagen, Denmark, 2013.

Endresen, Ø., Sørgård, E., Sundet, J. K., Dalsøren, S. B., Isaksen, I. S. A., Berglen, T. F., and Gravir, G.: Emission from international sea transportation and environmental impact, J. Geophys. Res., 108, 4560, doi:10.1029/2002JD002898, 2003.

EU: Directive 2012/33/EU of the European Parliament and of the Council of 21 November 2012 amending Council Directive 1999/32/EC as regards the sulphur content of marine fuels, Strasbourg, France, 2012.

Fioletov, V. E., McLinden, C. A., Krotkov, N., Yang, K., Loyola, D. G., Valks, P., Theys, N., Van Roozendael, M., Nowlan, C. R., Chance, K., Liu, X., Lee, C., and Martin, R. V.: Application of OMI, SCIAMACHY, and GOME-2 satellite $\mathrm{SO}_{2}$ retrievals for 
detection of large emission sources, J. Geophys. Res.-Atmos., 118, 11399-11418, 2013.

Ialongo, I., Hakkarainen, J., Hyttinen, N., Jalkanen, J.-P., Johansson, L., Boersma, K. F., Krotkov, N., and Tamminen, J.: Characterization of OMI tropospheric $\mathrm{NO}_{2}$ over the Baltic Sea region, Atmos. Chem. Phys., 14, 7795-7805, doi:10.5194/acp-14-77952014, 2014.

IHS Global: Chemin de la Mairie, Perly, Geneva, Switzerland, 2014.

International Maritime Organization (IMO): Regulations for the prevention of air pollution from ships and $\mathrm{NO}_{x}$ technical code, Annex VI of the MARPOL convention 73/78, London, UK, October 2008 .

Jalkanen, J.-P., Brink, A., Kalli, J., Pettersson, H., Kukkonen, J., and Stipa, T.: A modelling system for the exhaust emissions of marine traffic and its application in the Baltic Sea area, Atmos. Chem. Phys., 9, 9209-9223, doi:10.5194/acp-9-9209-2009, 2009.

Jalkanen, J.-P., Johansson, L., Kukkonen, J., Brink, A., Kalli, J., and Stipa, T.: Extension of an assessment model of ship traffic exhaust emissions for particulate matter and carbon monoxide, Atmos. Chem. Phys., 12, 2641-2659, doi:10.5194/acp-12-26412012, 2012.

Jalkanen, J.-P., Johansson, L., and Kukkonen, J.: A Comprehensive Inventory of the Ship Traffic Exhaust Emissions in the Baltic Sea from 2006 to 2009, Ambio, 43, 311-324, 2014.

Johansson, L., Jalkanen, J.-P., Kalli, J., and Kukkonen, J.: The evolution of shipping emissions and the costs of regulation changes in the northern EU area, Atmos. Chem. Phys., 13, 11375-11389, doi:10.5194/acp-13-11375-2013, 2013.

Jonson, J. E., Jalkanen, J. P., Johansson, L., Gauss, M., and Denier van der Gon, H. A. C.: Model calculations of the effects of present and future emissions of air pollutants from shipping in the Baltic Sea and the North Sea, Atmos. Chem. Phys., 15, 783798, doi:10.5194/acp-15-783-2015, 2015.

Kalli, J., Jalkanen, J.-P., Johansson, L., and Repka, S.: Atmospheric emissions of European SECA shipping: long-term projections, WMU J. Marit. Affairs, 12, 129-145, 2013.
Marmer, E., Dentener, F., Aardenne, J. V., Cavalli, F., Vignati, E., Velchev, K., Hjorth, J., Boersma, F., Vinken, G., Mihalopoulos, N., and Raes, F.: What can we learn about ship emission inventories from measurements of air pollutants over the Mediterranean Sea?, Atmos. Chem. Phys., 9, 6815-6831, doi:10.5194/acp-96815-2009, 2009.

Pirjola, L., Pajunoja, A., Walden, J., Jalkanen, J.-P., Rönkkö, T., Kousa, A., and Koskentalo, T.: Mobile measurements of ship emissions in two harbour areas in Finland, Atmos. Meas. Tech., 7, 149-161, doi:10.5194/amt-7-149-2014, 2014.

Schrooten, L., De Vlieger, I., Int Panis, L., Chiffi, C., and Pastori, E.: Emissions of maritime transport: A European reference system, Sci. Total Environ., 408, 318-323, 2009.

Starcrest: Port of Los Angeles Inventory of Air Emissions 2012, 2013.

Trafi: Finnish Transport Safety Agency, National small boat register, available at: http://www.veneily.fi/venerekisteri, last access: 24 November 2014.

USEPA: Regulatory impact analysis control of emissions of air pollution from locomotive engines and marine compression ignition engines less than 30 liters per cylinder, EPA/OTAQ, Washington DC, USA, 2008.

Vinken, G. C. M., Boersma, K. F., van Donkelaar, A., and Zhang, L.: Constraints on ship $\mathrm{NO}_{x}$ emissions in Europe using GEOSChem and $\mathrm{OMI}$ satellite $\mathrm{NO}_{2}$ observations, Atmos. Chem. Phys. 14, 1353-1369, doi:10.5194/acp-14-1353-2014, 2014.

Wang, C., Corbett, J. J., and Firestone, J.: Improving Spatial Representation of Global Ship Emissions Inventories, Environ. Sci. Technol., 42, 193-199, 2008.

Whall, C., Cooper, D., Archer, K., Twigger, L., Thurston, N., Ockwell, D., McIntyre, A., and Ritchie, A.: Quantification of emissions from ships associated with ship movements between ports in the European Community. Final report for European Commission by ENTEC UK Limited, London, UK, 2002. 